\title{
A case of the Dubin-Johnson syndrome complicated by acute hepatitis
}

\author{
RAJIV R. VARMA, JOHN M. GRAINGER, AND PETER J. SCHEUER \\ From the Departments of Medicine and Pathology, Royal Free Hospital, London
}

SUMMARY A patient is described in whom the Dubin-Johnson syndrome was diagnosed after an attack of acute hepatitis at the age of 21. In the eight years following the hepatitis Dubin-Johnson pigment, initially scanty, developed to classical proportions. The defect in intracellular transport of bilirubin was thought to precede the attack of acute hepatitis.

The Dubin-Johnson syndrome was described by Dubin and Johnson and Sprinz and Nelson in 1954. Many reports since then have clarified its clinical and laboratory aspects, but the fundamental abnormality causing the defect in intracellular transport of bilirubin and other substances is not known. The relationship of the abnormal hepatic pigmentation to the syndrome remains unexplained.

The present paper describes a patient who presented at the age of 21 years with an attack of acute hepatitis. Subsequently he showed a persistent hyperbilirubinaemia, and repeated biopsies of the liver demonstrated gradual accumulation of hepatocellular pigment.

This case shows that following presumed loss of pigment at the time of hepatocellular damage a massive amount of pigment may reaccumulate, in the course of several years.

\section{Case History}

C.D.M., a 21-year-old man, in November 1961, was noted to have mild but persistent icterus two days after tonsillectomy. Four weeks later, the jaundice deepened and anorexia, nausea, and vomiting developed. In March 1962 he noticed pruritus and was seen for the first time at the Royal Free Hospital. He gave no family history of jaundice. Physical examination revealed jaundice and scratch marks. A tender liver Received for publication 3 June 1970. edge was palpable, $2 \mathrm{~cm}$ below the right costal margin.

Laboratory investigations showed haemoglobin $14.3 \mathrm{~g}$ per $100 \mathrm{ml}$; packed cell volume $51 \%$; reticulocyte count less than $1 \%$; serum bilirubin $20 \mathrm{mg}$ (conjugated $14.3 \mathrm{mg}$ ) per $100 \mathrm{ml}$; prothrombin time $15 \mathrm{sec}$ (control $13 \mathrm{sec}$ ); aspartate transaminase 185 IU per litre; serum cholesterol $490 \mathrm{mg}$ per $100 \mathrm{ml}$; alkaline phosphatase 21 KA units. Barium swallow and meal were normal. He gradually improved on bed rest and a regular diet, but later became more deeply jaundiced. The serum bilirubin level rose to $10.8 \mathrm{mg}$ per $100 \mathrm{ml}$. Prednisone was prescribed and was followed by gradual recovery. He was discharged and steroids were gradually withdrawn. Mild, predominantly conjugated hyperbilirubinaemia persisted.

In April 1963 the patient was readmitted because he tired easily and had bouts of nausea. Physical examination was within normal limits.

Serum bilirubin was $1.6 \mathrm{mg}$ (conjugated $1.1 \mathrm{mg}$ ) per $100 \mathrm{ml}$; aspartate transaminase 7 IU per litre; alkaline phosphatase $8 \mathrm{KA}$ units per $100 \mathrm{ml}$; total protein $7 \cdot 3$ (albumin 5.1 and globulin 2.2) g per $100 \mathrm{ml}$. An extended bromsulphalein (BSP) test showed 35\%, 13.3\%, 5\%, $4.3 \%, 7.5 \%, 7 \%, 8.3 \%, 9.1 \%$, and $5.4 \%$ retention in $10,25,30,45,75,110,130,150$, and 210 minutes respectively.

In July 1964 the patient was in hospital because of recurrent right upper quadrant pain and nausea. An oral cholecystogram and an intravenous cholangiogram failed to demonstrate the 
biliary tree. The total and conjugated bilirubin levels were 4.2 and $3.4 \mathrm{mg}$ per $100 \mathrm{ml}$ respectively.

The patient was lost to follow up for some years as he had moved to another city, but it transpired later that he had been admitted to hospital on several occasions because of abdominal pain.

In November 1969 he was readmitted to the Royal Free Hospital when the serum bilirubin level was 2.5 (conjugated $2.0 \mathrm{mg}$ per $100 \mathrm{ml}$ ), aspartate transaminase 6 IU per litre, and serum cholesterol $240 \mathrm{mg}$ per $100 \mathrm{ml}$. A fourday telepaque cholecystogram (Salzman, Spurck, Kier, and Watkins, 1959; Lloyd, 1960) was done after attempts to see the biliary system with an oral cholecystogram and an intravenous cholangiogram, using standard techniques, had failed. The biliary tree was faintly visualized and appeared normal. The UDP-bilirubin glucuronyl transferase activity in liver biopsy tissue (Black, Billing, and Heirwegh, 1970) was within normal limits. An extended BSP test showed $26 \%$ retention at 210 minutes and $21 \%$ at 24 hours.

\section{LIVER BIOPSY FINDINGS}

The first percutaneous liver biopsy, taken in March 1962, consisted of a cylinder $1.3 \mathrm{~cm}$ in length, mottled green after formalin fixation. Microscopically, mild condensation of reticulin was seen in centrilobular areas, and the portal tracts were enlarged. Acute and chronic inflammatory cells infiltrated both the portal areas and the lobules, and at the centres of the lobules there was liver cell necrosis and much pigment of 'ceroid' type in Kupffer cells (Fig. 1). The appearances were those of an acute hepatitis, and were consistent with a viral aetiology.

The second liver biopsy, taken in April 1963, was $3 \mathrm{~cm}$ in length and black-green after formalin fixation. Microscopically the tissue was normal except for the presence of large amounts of fine brown pigment granules at the biliary poles of the centrilobular liver cells (Fig. 2, left). There were few granules in the Kupffer cells. The diagnosis was considered to be Dubin-Johnson syndrome but some doubt remained because of the small size of the granules.

The third liver biopsy, taken in November 1969, consisted of four green-black mottled cylinders. Microscopically the appearances were similar to the biopsy of 1963 , but more pigment was present and the pigment granules were larger and more variable (Fig. 2, right). Some pigment was again seen in the Kupffer cells. The appearances were now typical of Dubin-Johnson syndrome.

\section{ELECTRON MICROSCOPY}

A small part of the third biopsy was fixed in iso-osmotic phosphate buffer with $1 \%$ osmic acid. After fixation it was dehydrated in graded

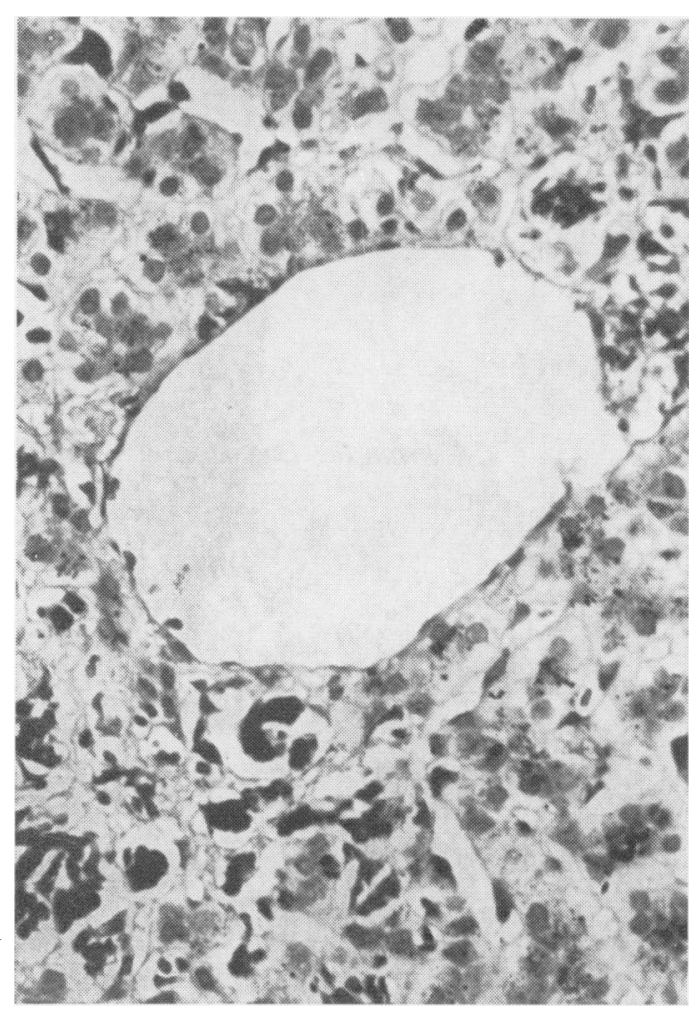

Fig. 1 Biopsy 1 (1962) which shows a centrilobular area and a central vein. There is swelling of cells and necrosis, and Kupffer cells contain PAS-positive material (diastase-PAS, $\times 500$ ).

alcohols and embedded in Epon 812. Section were stained with Reynold's lead stain and examined in a Siemens Elmiskop 1 electron microscope.

The pigment seen by light microscopy corresponded to well defined masses of round, oval, and often bluntly angled outline which were approximately 1 to $5 \mu$ across. There was a single limiting membrane beneath which was an inconstant thin electron-lucent zone. Within the mass were globules, usually osmiophilic and dense, but sometimes with lucent centres. The larger part of the mass, however, was of variable but usually moderate density and was granular or finely filamentous (Fig. 3).

The appearances were those of the DubinJohnson syndrome. Not all the masses were similar in structure. Those with a high content of globular densities showed a polymorphous outline and resembled lipofuscin in structure.

Following the demonstration of DubinJohnson pigment in the third biopsy, a small and darker part of the first biopsy was cut from the paraffin block. This was hydrated, treated with $1 \%$ osmic acid, and processed as described for the third biopsy. Although fixation was not ideal, granules of Dubin-Johnson type could be 

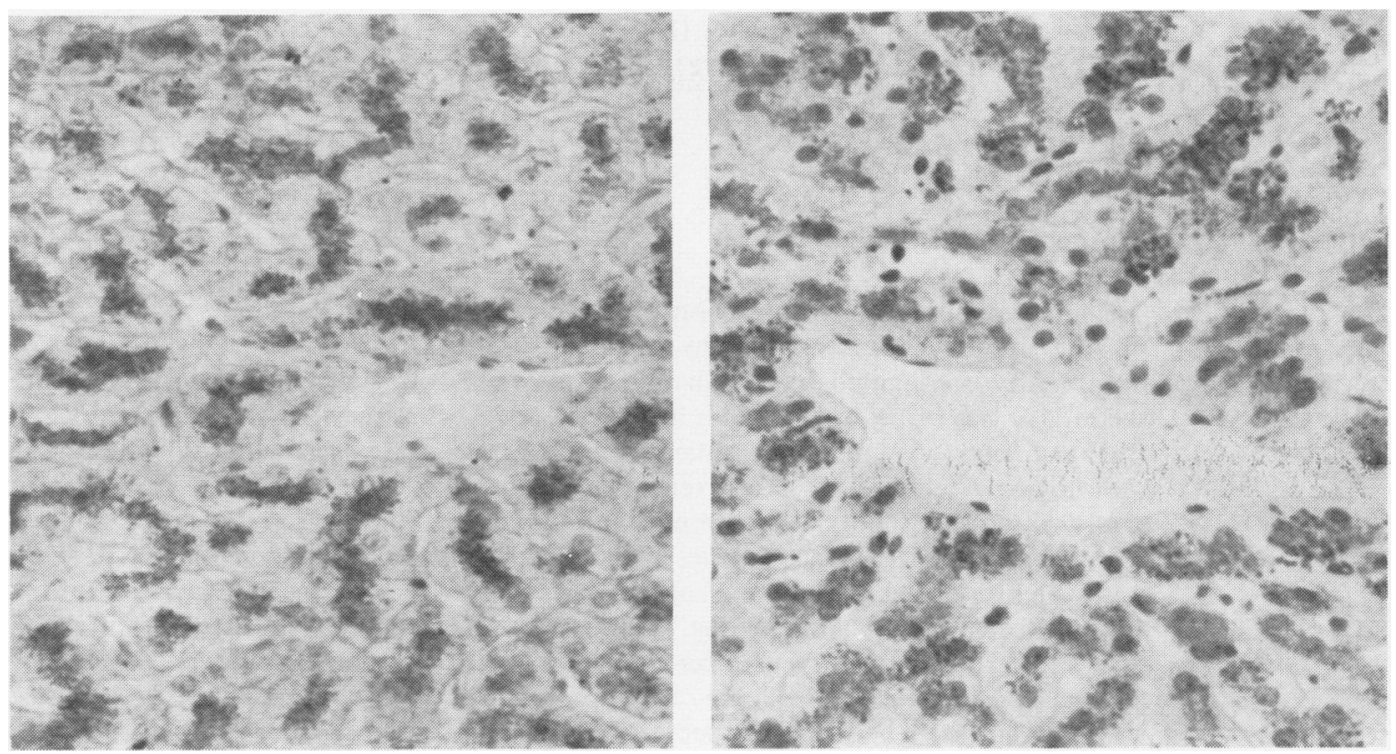

Fig. 2 Left Biopsy 2 (1963) showing a centrilobular area with large amounts of pericanalicular pigment in liver cells (Ziehl-Neelsen, $\times 400$ ).

Right Biopsy 3 (1969) showing a centrilobular area for comparison with biopsy 2. The granules are larger, and the amount of pigment greater and often distributed throughout the cell (Ziehl-Neelsen, $\times 400$ ).
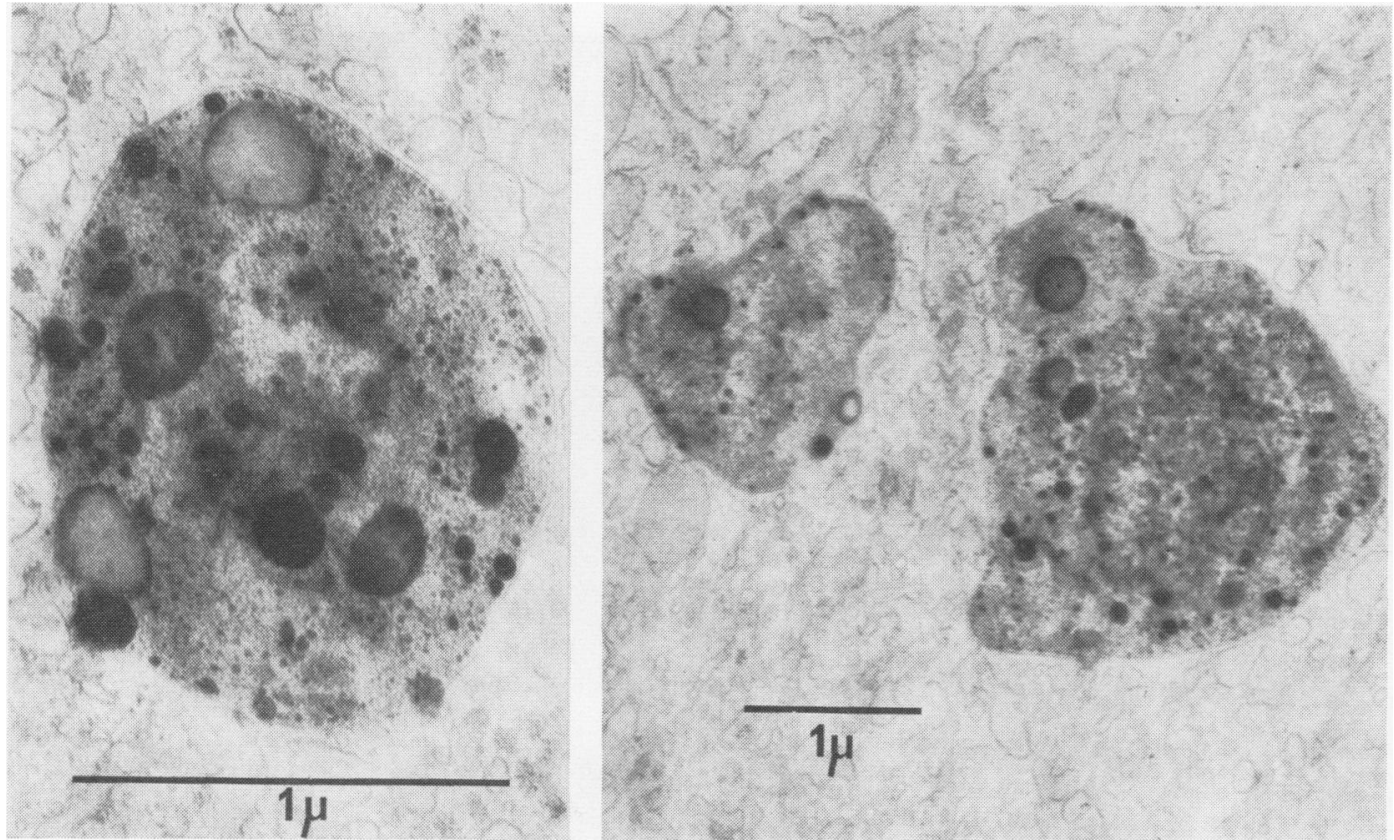

Fig. 3 Left Biopsy 3 (1969). Electron micrograph showing a pigment granule with globular densities in a matrix which is finely granular. There is a single surrounding membrane beneath which lies a thin translucent zone $(\times 50,000)$.

Right Part of same biopsy $(\times 20,000)$. 
demonstrated in the hepatocytes (Fig. 4). Larger numbers of dense granules were present in the Kupffer cells.

\section{Discussion}

The diagnosis of the Dubin-Johnson syndrome in our patient is established by chronic, predominantly conjugated hyperbilirubinaemia, the secondary rise in bromsulphalein in the extended BSP test, poor visualization of the biliary tree by radiological techniques, recurrent abdominal symptoms, and, finally, the presence of typical pigment granules in liver biopsies, as shown by both light and electron microscopy (Toker, 1965; Sherlock, 1968; Barone, 1969). It remains uncertain, however, whether the syndrome preceded an attack of acute and probably viral hepatitis, whether the hepatitis revealed a latent form of the syndrome, or whether this initiated the disorder. The history of otherwise unexplained jaundice before the hepatitis points to the first of these possibilities, as does the finding of granules of Dubin-Johnson type on electron microscopy of a liver biopsy taken at the time of hepatitis.

Loss from the liver cells of the typical pigment in patients with the Dubin-Johnson syndrome during acute viral hepatitis has been reported by Hunter (1964) and Masuda (1965). The patient reported by Hunter died four months after the attack of hepatitis, and at necropsy the centrilobular liver cells contained scanty pigment granules. In the patient described by Masuda (1965) a liver biopsy taken three months after the onset of hepatitis showed loss of the DubinJohnson pigment. In our case the Dubin-Johnson syndrome was not diagnosed until after the attack of acute hepatitis. In one year sufficient pigment had accumulated in the liver cells to suggest the diagnosis, although the pigment had not yet become as coarse as is usual in the typical case. It appears that parenchymal damage causes release of the pigment which is then seen in the Kupffer cells. Dubin and Johnson (1954) postulated that in one of their cases focal cell necrosis led to release of the pigment which was then taken up by macrophages. The increase in BSP retention over the years is in keeping with the suggestion of Wolf, Pizette, Richman, Dreiling, Jacobs, Fernandez, and Popper (1960) that this may be proportional to the degree of liver cell pigmentation.

Several authors have noted marked variation in the amount of pigment between different patients, and indeed between affected members of the same family (Wolf et al, 1960; Arias, 1961; Butt, 1966). Our case demonstrates that

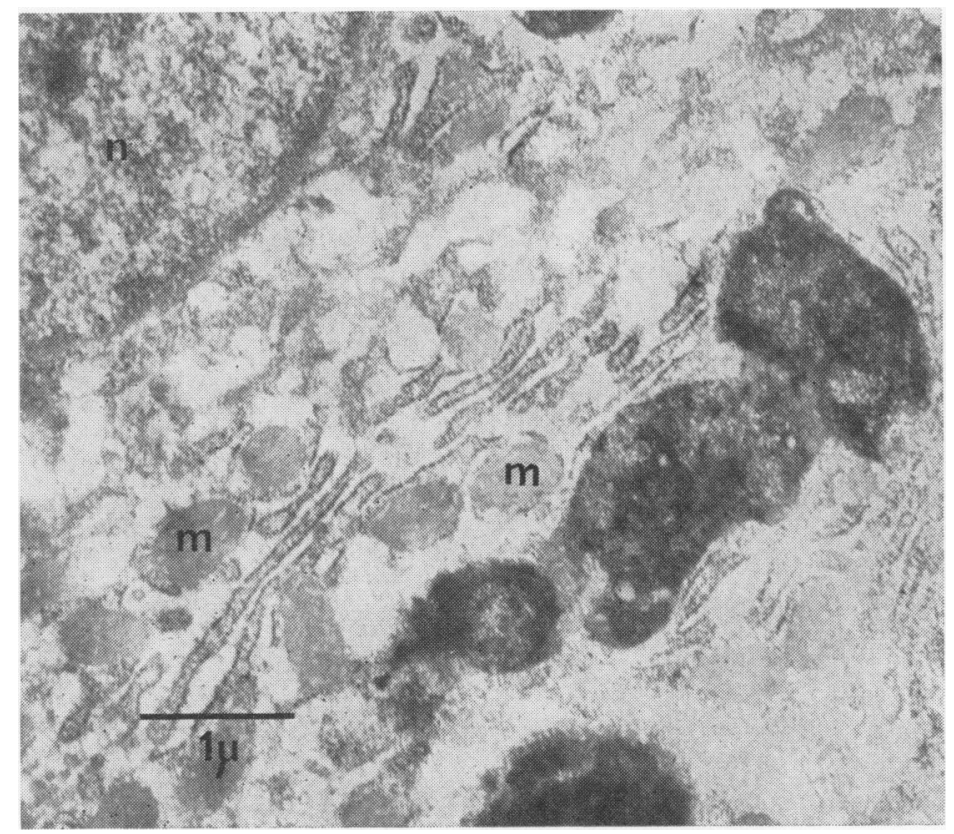

Fig. 4 Biopsy 1 (1962) in which tissue was cut from the formalin-fixed paraffin block eight years after it had been embedded. Fixation for electron microscopy is not ideal but the granules have a similar appearance to those seen in Figure 3; $\mathrm{n}=$ nucleus, $\mathrm{m}=$ mitochondria $(\times 20,000)$. 
much variation may occur in a single liver, not only at the time of presumably incidental liver damage but also years later. This supports the suggestion that variation in liver pigmentation from patient to patient may depend on external as well as genetic factors.

We wish to thank Dr David Douglas for referring the patient. The UDP-bilirubin glucuronyl transferase estimation of the hepatic biopsy was kindly performed by Dr Martin Black.

This work was supported by a grant from the Wellcome Trust.

References

Arias, I. M. (1961). Studies of chronic familial non-hemolytic jaundice with conjugated bilirubin in the serum with and without an unidentified pigment in the liver cells. Amer.J. Med., 31, 510-518.

Barone, P., Inferrera, C., and Carrozza, G. (1969). In Pigments in Pathology, edited by M. Wolman. Academic Press, New York.

Black, M., Billing, B. H., and Heirwegh, K. P. M. (1970). Determination of bilirubin UDP-glucuronyl transferase activity in needle-biopsy specimens of human liver. Clin. chim. Acta, 29, 27-35.
Butt, H. R., Anderson, V. E., Foulk, W. T., Baggenstoss, A. H. Schoenfield, L. J., and Dickson, E. R. (1966). Studies of chronic idiopathic jaundice (Dubin-Johnson syndrome). II. Evaluation of a large family with the trait. Gastroenterology, 51, 619-630.

Dubin, I. N., and Johnson, F. B. (1954). Chronic idiopathic jaundice with unidentified pigment in liver cells. Medicine (Baltimore), 33, 155-197.

Hunter, F. M., Sparks, R. D., and Flinner, R. L. (1964). Hepatitis with resulting mobilisation of hepatic pigment in a patient with Dubin-Johnson syndrome. Gastroenterology, 47, 631-635.

Lloyd, G. A. S. (1960). The 'four day telepaque test' in the investigation of the post cholecystectomy syndrome. Brit. J. Radiol., 33, 522-523.

Masuda, M. (1965). On the relation between Dubin-Johnson syndrome and Rotor type. A case of Dubin-Johnson syndrome complicated with serum hepatitis. Rev. int. Hepat., 15, 1227-1232.

Salzman, E., Spurck, R. P., Kier, L. C., and Watkins, D. H. (1959). Opacifying gallstones. J. Amer. med. Ass., 169, 334-338.

Sherlock, S. (1968). Diseases of the Liver and Biliary System, 4th ed. Blackwell, Oxford.

Sprinz, H., and Nelson, R. S. (1954). Persistent non-hemolytic hyperbilirubinemia associated with lipochrome-like pigment in liver cells: report of four cases. Ann. intern. Med., 41, 952-962.

Toker, C., and Trevino, N. (1965). Hepatic ultrastructure in chronic idiopathic jaundice. Arch. Path., 80, 453-460.

Wolf, R. L., Pizette, M., Richman, A., Dreiling, D. A., Jacobs, W. Fernandez, O., and Popper, H. (1960). Chronic idiopathic jaundice. Amer. J. Med., 28, 32-41. 